\title{
Blueschists and Blue Amphiboles: How Much Subduction Do They Need?
}

\author{
WALTER V. MARESCH ${ }^{1}$ \\ Institut für Geologie, Mineralogie, und Geophysik, Ruhr-Universität Bochum, 44780 Bochum, Germany
}

AND TARAS V. GERYA

Geologisches Institut, ETH - Zürich, CH-8092 Zürich, Switzerland; Institut für Geologie, Mineralogie, und Geophysik, Ruhr-Universität Bochum, 44780 Bochum, Germany; and Institute of Experimental Mineralogy, Russian Academy of Sciences, Chernogolovka, Moscow District, 142432, Russia

\begin{abstract}
We focus on blueschist formation in evolving, nascent intra-oceanic subduction zones where cessation of subduction, e.g., by collision with continental margins, preserves the first-formed blueschist products. The Caribbean area provides a case study for a tectonic regime that has led to obducted blueschist occurrences without obvious coeval volcanism, raising the question of the minimum subduction duration and amount of convergence necessary to produce them. Systematic numerical modeling shows that for slab ages of 20-100 Ma and subduction rates of 2-14 $\mathrm{cm} / \mathrm{yr}$ blueschist-facies conditions can be attained in only 0.25 to 3 m.y., with amounts of total convergence ranging between 35 and $75 \mathrm{~km}$. Because of the geometrical interplay between the subducting slab "nose" and the evolving array of isotherms, younger and hotter slabs can lead to earlier blueschist formation than older, cooler slabs. There is a distinct optimum for slabs between 40 and 60 m.y. In principle, Andean-type, continental margin models yield almost identical values. Depending on the specific exhumation scenario, the time required for exhumation must in general be added to the minimum life span of the subduction zone.
\end{abstract}

\section{Introduction}

IT IS A PLEASURE and privilege to contribute to a compilation of papers dedicated to honoring the impact of W. Gary Ernst's career on the Earth sciences. $^{2}$ Gary has accompanied, steered, and decidedly influenced studies on the subduction process ever since the "early days" about 40 years ago, when his studies in metamorphic and experimental petrology (e.g., Ernst, 1963) emphasized the necessity for high $\mathrm{dP} / \mathrm{dT}$ geotherms during the orogenic process. Such ideas were not necessarily popular in all quarters, and it is a further credit to Ernst's influence and perseverance that he steadily and patiently collected, presented, and honed the scientific arguments that contributed to a convincing subduction model. Since these early days, subduction has come to be viewed as a "factory" in a twofold sense of the word. On the one hand, "factory" describes in a

\footnotetext{
${ }^{1}$ Corresponding author; email: walter.maresch@rub.de.

${ }^{2}$ This paper is subsequently scheduled for republication in a forthcoming volume of papers honoring W. G. Ernst's contributions to geology in general and the study of high-pressure metamorphism more specifically.
}

fitting way the interconnected processes that produce crust (i.e., metamorphic and magmatic rocks: Eiler, 2004; Hacker et al., 2003; Tatsumi and Kogiso, 2003) from raw materials such as sediments, oceanic crust, and mantle lithosphere, and, on the other hand, the voluminous literature on the subject now being churned out at an unprecedented rate on this key element of System Earth's processes.

In this contribution we propose to take modern, state-of-the-art methodology and return to the first harbingers of high-pressure, subduction-related metamorphism. Given that blueschists and the relatively aluminous and magnesian blue amphiboles they contain are classical indicators for the sites of fossil subduction zones, and should be the first evidence to develop in a maturing subduction zone, we propose to use numerical methods to quantify how much time and how much subduction are actually needed to produce the first blueschists after the birth of a subduction zone.

In the present study we focus on intra-oceanic subduction zones for two reasons. As summarized by Leat and Larter (2003), a significant $40 \%$ of modern subduction zones on Earth are intra-oceanic. These 


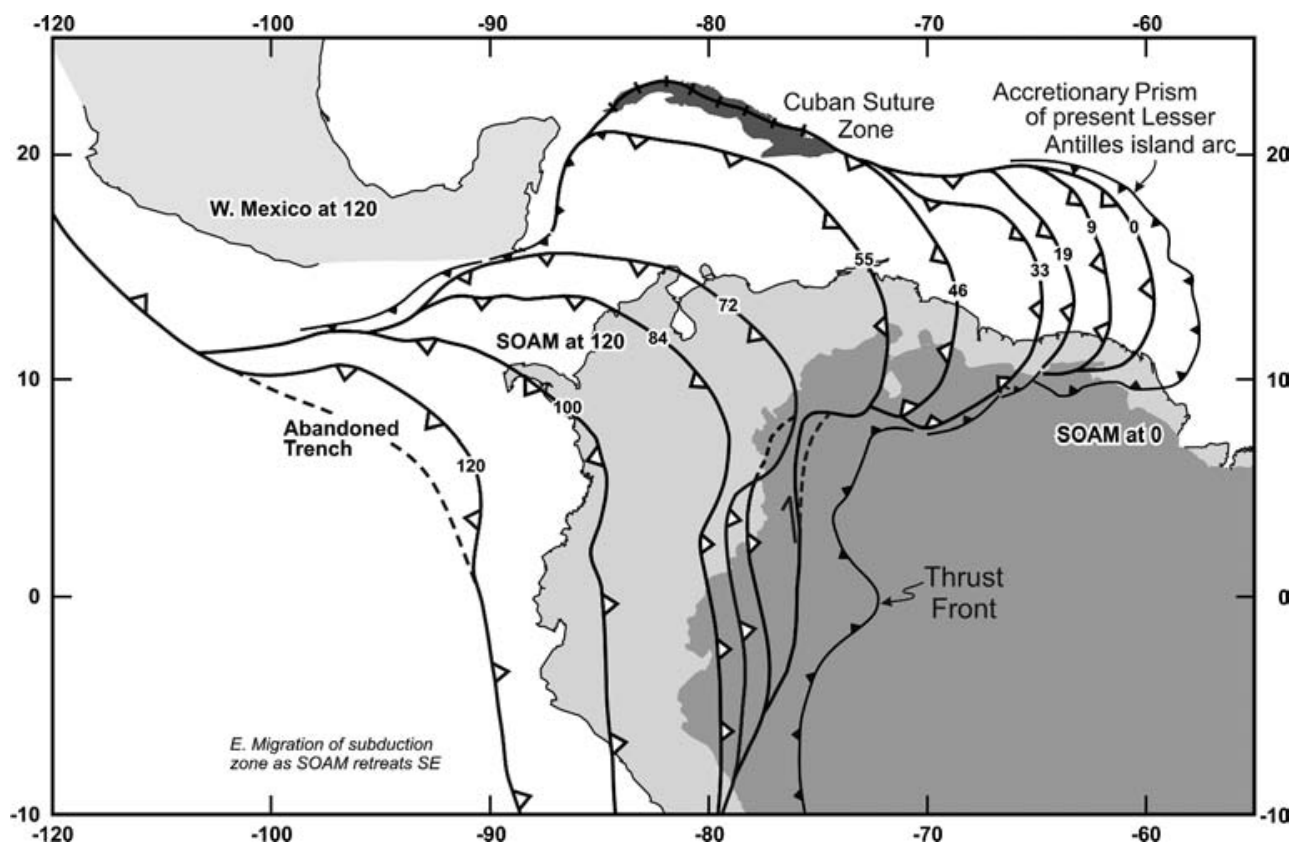

FIG. 1. Relative eastward advance of the Caribbean plate from the Pacific with respect to North America (proxied by western Mexico in this representation) and South America (SOAM) with time (all ages are in Ma), as derived from the detailed plate tectonic model of Pindell and Kennan (2001). The bow of the plate is the location of an intra-oceanic subduction zone system called the "Great Arc" by Burke (1988). The widening gap between North and South America is indicated by the relative positions of South America at $120 \mathrm{Ma}$ and 0 Ma. Complex interaction between the oceanic Great Arc and North as well as South America has led to obduction and suturing of blueschists and other high-pressure rock sequences to the northern and southern continental margins of the Caribbean (Pindell et al., 2005).

subduction systems are generally simpler than those at continental margins, and therefore easier to understand (e.g., Leat and Larter, 2003). They also commonly have a shorter history of subduction, and they tend to be more mobile. On the other hand, these modern intra-oceanic arcs (most of which are found along the Southwest Pacific rim) have received much less attention, because of their largely inaccessible character in remote parts of the world or well below the surface of the sea. It is therefore of great interest to study older examples that have collided with and were obducted onto continental margins (e.g., Clift et al., 2003), with concomitant shutdown of the "subduction factory" and emphasis on the preservation of prograde features. The present study draws on both of these aspects. The numerical approach employed uses a conceptual model patterned after intra-oceanic subduction zones to address questions that have arisen from studies of arc systems that have swept through the Caribbean area during the last 120 m.y.

\section{The Caribbean Example: Definition of the Problem}

In many respects, the history of the Caribbean area suggests strong similarities with the systems of island arcs now characterizing the Southwest Pacific, or with the Tethys realm before closure (e.g., Maresch, 1974; Burke, 1988; Meschede and Frisch, 1998; Kerr et al., 1999; Pindell and Kennan, 2001; Pindell et al., 2005, among many others). Island arcs in such settings are probably very mobile, constantly evolving and individually may be short lived. They need not reach the dynamic equilibrium we usually expect in textbook examples. In keeping with the scenario of rapidly evolving systems of intra-oceanic island arcs interacting with each other and the continental margins of North and South America, there are diverging ideas on the actual details of Caribbean plate tectonic models.

The summary and synthesis of Pindell et al. (2005) suggest that the model outlined in Figure 1 fits the presently available data on the geological 
history of the circum-Caribbean margins well. This model serves as a template for Figure 1, which schematically shows the inferred progress of a Pacific plate moving relatively eastward between North and South America as these rift apart, overriding and subducting first newly formed Protocaribbean and then Atlantic oceanic lithosphere. Burke (1988) coined the term "Great Arc" to describe the system of intra-oceanic arcs marking the front of the eastwardly progressing Pacific lobe, whose present eastward position is indicated by the accretionary prism of the Lesser Antilles intra-oceanic arc. Because the "Great Arc" must lengthen and change shape during its progress, subduction zones and related island arcs must be continuously evolving. It is also postulated that at $\sim 120 \mathrm{Ma}$ the east-dipping subduction zone bridging the gap between North and South America must have reversed direction to allow eastward migration (Fig. 1). Progressive, very oblique eastward collision along the northern and southern margins of the Caribbean led to obduction of the high-pressure metamorphic rocks now found from Guatemala and Cuba in the NW Caribbean via Jamaica, the Dominican Republic, and Venezuela to Colombia in northwestern South America (see detailed summary by Pindell et al., 2005). One of the largest examples is the blueschist-dominated Villa de Cura complex in northern Venzuela (e.g., Smith et al., 1999; Pindell et al., 2005), an obducted block $250 \mathrm{~km}$ by $30 \mathrm{~km}$ in exposed areal extent.

Clearly, it is of general interest to gauge the amount of time that elapsed between the birth of a particular subduction zone segment and its shut-down by obduction and suturing. Because of the highly oblique angle of collision along the southern margin, obduction was generally followed by strike-slip shearing with almost no post-collisional volcanism. Rapid exhumation of high-pressure rocks is also postulated to have occurred by arc-parallel extension prior to obduction (Avé Lallemant and Guth, 1990; Avé Lallemant, 1997). In the north, a southward jump of the collision zone has decoupled and preserved the suture zone well, as for instance in Cuba. Obduction in such an arc-continent collision can be expected to take place in less than 2-3 Ma (e.g., Clift et al., 2003). No further subduction was available to exhume the high-pressure rocks, as required in more mature situations with return flow in so-called subduction channels (e.g., Hsu, 1971; Cloos, 1982; Cloos and Shreve, 1988a, 1988b; Shreve and Cloos, 1986). The current plate tectonic model of Pindell and Kennan (2001) also incorporates ideas on early back-arc spreading in northwestern South America (Fig. 2), before relative eastward movement of the Pacific plate closed this spreading "wedge." Such models (e.g., Pindell and Erikson, 1994; Pindell et al., 2005) attempt to relate isolated occurrences of blueschist in the northern Andes well inland of the Pacific to closure of such a backarc basin. This raises another interesting question. How wide must a backarc basin be to produce blueschists after closure and subduction of such young oceanic crust?

\section{Numerical Modeling: Design and Implementation}

\section{Initial and boundary conditions of the 2-D model}

We use a newly designed regional 2-D model that takes into account the process of hydration of the mantle wedge by the fluid released from a kinematically described subducting plate (e.g., Gerya et al., 2002, 2004; Gerya and Yuen, 2003a). Figure 3 shows the initial (panel a) and boundary (panel b) conditions and the hydration model used (panel c). We assume that dehydration of the subducting slab liberates an upward migration of aqueous fluid, resulting in the hydration of the mantle wedge near the slab (see panel c). This hydration leads to a sharp decrease in density and viscosity of the mantle rocks, creating favorable conditions for the development of a weak hydrated zone along the plate interface (Gerya et al., 2002; Gerya and Yuen, 2003a).

We use a simplified layered structure of subducting oceanic crust of $8 \mathrm{~km}$ thickness (Fig. 3A), composed of sedimentary $(1 \mathrm{~km})$, basaltic $(2 \mathrm{~km})$, and gabbroic $(5 \mathrm{~km})$ layers characterized by different physical properties (Table 1). The position of the incipient subduction zone (Fig. 3A) is imposed using a weak, $8 \mathrm{~km}$ thick layer composed of hydrated peridotite (e.g., Regenauer-Lieb et al., 2001). During modeling of the subduction process, this weak zone is spontaneously replaced by weak, subducted crustal rocks and hydrated mantle, implying a decoupling along the plate interface. The initial temperature field in both the subducting and overriding plates (Fig. 3A) is defined by an oceanic geotherm $T_{0}(z)$ based on a cooling half-space model with a specified age.

The kinematic boundary conditions (Fig. 3B) correspond to the corner flow model (e.g., Gerya and Yuen, 2003a) and simulate asthenospheric mantle flow at temperatures exceeding $1000^{\circ} \mathrm{C}$ in the 


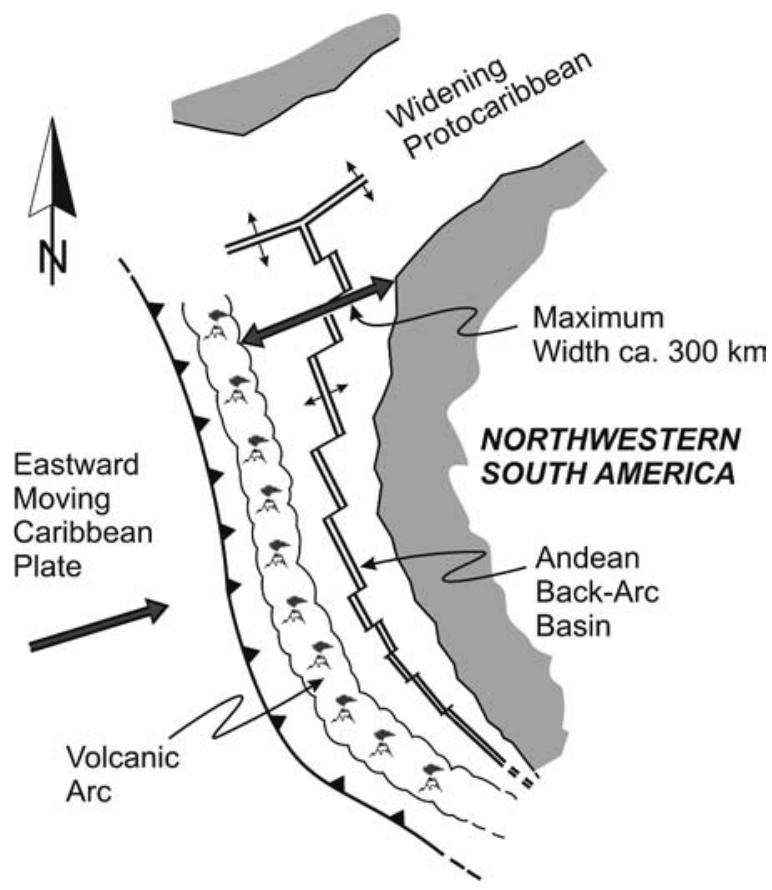

FIG. 2. Backarc basin suggested for northwest South America in the plate tectonic model of Pindell and Kennan (2001) during the early Aptian (119 Ma). Can closure of such a narrow basin and subduction of this young warm crust lead to the isolated belts of blueschists now found in the northern Andes?

mantle wedge. To insure a smooth continuity of the temperature field across the lower boundary of the truncated regional model, we use an infinite-like boundary condition involving vanishing changes of the vertical Lagrangian heat flux, $q_{z}$, with depth $\left(\partial q_{z}\right.$ $/ \partial z=0$; Gerya and Yuen, 2003a).

The upper surface is calculated dynamically at each time-step like a free surface. To account for changes in the topography, we use a layer with a lower viscosity $\left(10^{18} \mathrm{~Pa} \cdot \mathrm{s}\right)$, whose initial thickness is $8 \mathrm{~km}$ on top of the oceanic crust. The density of this layer is taken to be $1 \mathrm{~kg} / \mathrm{m}^{3}$ (air) at $z<4 \mathrm{~km}$ and $1000 \mathrm{~kg} / \mathrm{m}^{3}$ (sea water) at $z>4 \mathrm{~km}$. An interface between this layer and the top of the oceanic crust is considered to be the erosion/sedimentation surface, which evolves according to the following transport equation, solved at each time step:

$$
\partial z_{\mathrm{es}} / \partial t=v_{z}-v_{x} \partial z_{\mathrm{es}} / \partial x-v_{s}+v_{e},
$$

where $z_{\mathrm{es}}$ is the vertical position of the surface as a function of the horizontal distance, $x ; v_{z}$ and $v_{x}$ are the vertical and horizontal components of the material velocity vector at the surface; $v_{s}$ and $v_{e}$ are, respectively, sedimentation and erosion rates corresponding to the relation

$$
\begin{gathered}
v_{s}=0 \mathrm{~mm} / \mathrm{a}, v_{e}=1 \mathrm{~mm} / \mathrm{a} \text { when } z<4 \mathrm{~km}, \\
v_{s}=0.3 \mathrm{~mm} / \mathrm{a}, v_{e}=0 \mathrm{~mm} / \mathrm{a} \text { when } z>4 \mathrm{~km} .
\end{gathered}
$$

\section{Dehydration and hydration models}

To account for the effects of the hydration process (Fig. 3C) in a viscous medium, we describe the vertical displacement of the hydration front (i.e., the interface between hydrated and dry mantle rock) with respect to the upper surface of the subducting slab (in Eulerian coordinates) by the following transport equation (Gerya et al., 2002), which is solved at each time-step:

$$
\partial z_{\mathrm{h}} / \partial t=v_{z}-v_{x} \partial z_{\mathrm{h}} / \partial x-v_{h},
$$

where $z_{\mathrm{h}}$ is the vertical location of the hydration front as a function of the horizontal distance, $x$, measured from the trench; $v_{\mathrm{h}}$ is the hydration rate; and $v_{\mathrm{z}}$ and $v_{\mathrm{x}}$ are the vertical and horizontal components of the material velocity vector at the front.

It has been shown (e.g., Peacock, 1987) that the availability of water controls the progress of mantle 

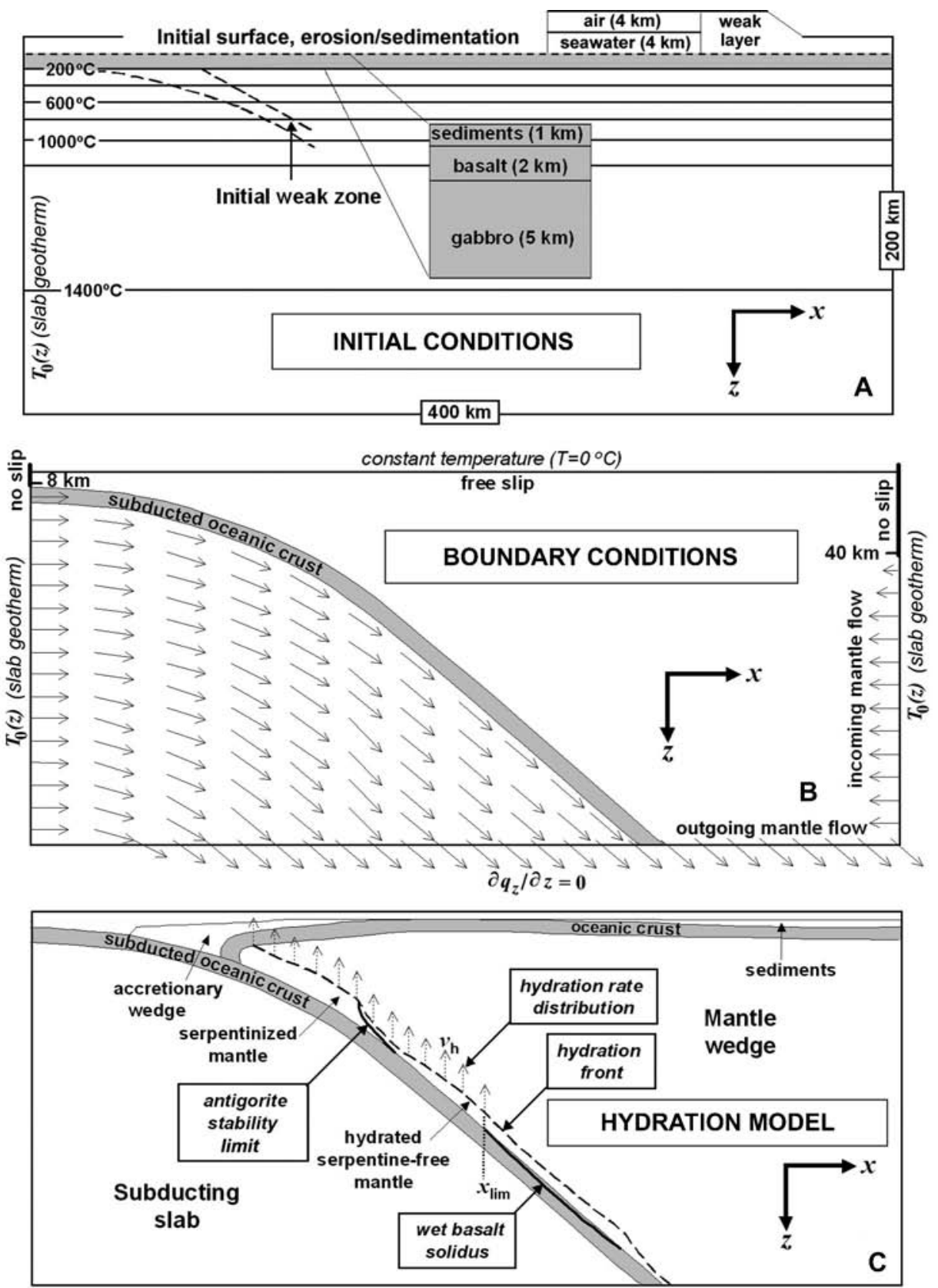

FIG. 3. Design of (A) initial and (B) boundary conditions, as well as (C) hydration model of the mantle wedge as used in our 2-D numerical experiments. See text for details.

hydration. We assume, therefore, that spatial changes in the hydration rate along the hydration front should mainly depend on spatial changes in the rate of fluid release along the surface of the subducting plate. Assuming a continuous (Schmidt and Poli, 1998) dehydration of the subducting slab, we also account for the vertical displacement of the hydration front (Fig. 3) in the deforming mantle 
TABLE 1. Material Properties Used in 2-D Numerical Experiments ${ }^{1}$

\begin{tabular}{|c|c|c|c|c|}
\hline Material & $\begin{array}{c}\rho, \\
\mathrm{kg} / \mathrm{m}^{3}\end{array}$ & $\begin{array}{l}\text { Thermal } \\
\text { conductivity, } \\
\mathrm{W} /(\mathrm{m} \cdot \mathrm{K})\end{array}$ & Rheology & $\begin{array}{c}H_{\mathrm{r}} \\
\mu \mathrm{W} / \mathrm{m}^{3}\end{array}$ \\
\hline Sedimentary rocks & 2700 & $0.64+\frac{807}{T+77}$ & Wet quartzite flow law, $\lambda_{10}=0.95$ & 2 \\
\hline Basaltic crust & 3100 & $1.18+\frac{474}{T+77}$ & Constant viscosity $10^{19} \mathrm{~Pa} \cdot \mathrm{s}$ & 0.25 \\
\hline Gabbroic crust & As above & as above & Plagioclase $\left(\mathrm{An}_{75}\right)$ flow law, $\lambda=0.95$ & As above \\
\hline Serpentinized mantle & 3000 & $0.73+\frac{1293}{T+77}$ & Constant viscosity $10^{19} \mathrm{~Pa} \cdot \mathrm{s}$ & 0.022 \\
\hline $\begin{array}{l}\text { Hydrated mantle beyond } \\
\text { the serpentine stability } \\
\text { field }^{2}\end{array}$ & 3300 & As above & Wet olivine flow law, $\lambda_{10}=0.95$ & As above \\
\hline Dry mantle & 3300 & As above & Dry olivine flow law, $\lambda_{10}=0$ & As above \\
\hline References & $\begin{array}{c}\text { Turcotte and } \\
\text { Schubert, } 1982\end{array}$ & $\begin{array}{c}\text { Clauser and } \\
\text { Huenges, } 1995\end{array}$ & Gerya et al., 2002; Ranalli, 1995 & $\begin{array}{c}\text { Turcotte and } \\
\text { Schubert, } 1982\end{array}$ \\
\hline
\end{tabular}

${ }^{1} \lambda=$ pore fluid pressure coefficient (see Eq. 5 in text); $\mathrm{p}=$ density (see Eq. 9 in text); $H_{\mathrm{r}}=$ radioactive heat production (see Eq. 10 in text).

${ }^{2}$ The serpentine stability field (Schmidt and Poli, 1998): $T>751+0.18 \mathrm{P}-0.000031 P^{2}$ at $\mathrm{P}<2100 \mathrm{MPa}, T>$

$1013-0.0018 \mathrm{P}-0.0000039 P^{2}$ at $\mathrm{P}>2100 \mathrm{MPa}$.

wedge with respect to the upper interface of the subducting slab. Hydration leads to a sharp decrease in density and viscosity of the mantle rocks, creating favorable conditions for corner flow in a wedge- shaped subduction channel. The hydration rate, $v_{\mathrm{h}}$, is approximated (Gerya et al., 2002) by a linear function of the horizontal distance, $x$, measured from the trench (Fig. 3):

$$
\begin{gathered}
v_{\mathrm{h}} / v_{\mathrm{s}}=\mathrm{A}\left[1-\mathrm{B} x / x_{\lim }\right] \text { when } x<x_{\lim }, \\
v_{\mathrm{h}} / v_{\mathrm{s}}=0 \text { when } x>x_{\lim },
\end{gathered}
$$

where $v_{\mathrm{s}}$ is the subduction rate; and $x_{\lim }$ is the limiting horizontal distance from the trench beyond which fluid release from the subducting plate is negligible (Gerya et al., 2002). The nondimensional parameter $B$ may vary from -1 to +1 , characterizing either the increase $(B<0)$ or the decrease $(B>0)$ in hydration rate with depth. The parameter $\mathrm{A}$ is a nondimensional intensity in the hydration process of the mantle wedge. Typical values of the parameter A range between 0.01 and 0.30 as a function of $(1)$ the water contents in the hydrated peridotite and (2) the total amount of water released from the subducting plate within the limiting distance $x_{\lim }$ (Gerya et al., 2002). In the present study we set $A=0.035$ and $\mathrm{B}=0$.

\section{Rheological model}

For materials of the crust and mantle, we employ a composite viscous rheology that encompasses the variability of the lithological phases (Table 1), temperature, and strain rate. The effective dislocation creep viscosity of rocks depending on stress and temperature is defined in terms of deformation invariants according to Ranalli (1995):

$$
\eta_{\text {disl }}=\left(\dot{\varepsilon}_{\text {II }}\right)^{(1-\mathrm{n}) / 2 \mathrm{n}} F\left(A_{D}\right)^{-\mathrm{l} / \mathrm{n}} \exp (E / \mathrm{n} R T),
$$

where $\dot{\varepsilon}_{\mathrm{II}}=1 / 2 \dot{\varepsilon}_{i j} \dot{\varepsilon}_{i j}$ is the second invariant of the strain-rate tensor, with dimension $\mathrm{s}^{-2} ; A_{D}, E$, and $\mathrm{n}$ are experimentally determined flow law parameters (Ranalli, 1995). $F$ is a dimensionless coefficient depending on the type of experiment on which the flow law is based (e.g., $F=2^{(1-n) / n} / 3^{(1+n) / 2 n}$ for triaxial compression and $\mathrm{F}=2^{(1-2 \mathrm{n}) / \mathrm{n}}$ for simple shear). 
The strength of solid rock in the brittle field is implemented as a limiting maximum viscosity

$$
\eta_{\text {max }}=\sigma_{\text {yield }} /\left(4 \dot{\varepsilon}_{\text {II }}\right)^{1 / 2},
$$

where $\sigma_{\text {yield }}=\left(\mathrm{N}_{1} P_{\text {lith }}+\mathrm{N}_{2}\right)(1-\mathrm{M})$ is the yield stress; $P_{\text {lith }}$ is the lithostatic pressure, $\mathrm{MPa} ; \mathrm{N}_{1}$ and $\mathrm{N}_{2}$ are empirical constants, MPa: $\mathrm{N}_{1}=0.85, \mathrm{~N}_{2}=0<\sigma_{\text {vield }}$ $<200 \mathrm{MPa}$ and $\mathrm{N}_{1}=0.6, \mathrm{~N}_{2}=60$ when $\sigma_{\text {yield }}>200$ $\mathrm{MPa}$ (Brace and Kohlstedt, 1980); and M is the pore fluid pressure coefficient (Table 1).

Finally, an effective creep viscosity $\eta$ is calculated according to a formula (e.g., Schott and Schmeling, 1998) providing smooth transitions between different regimes of deformation

$$
1 / \eta=1 / \eta_{\text {disl }}+1 / \eta_{\max }
$$

\section{Mathematical modeling \\ and numerical implementation}

We consider 2-D creeping flow wherein buoyant forces are included. The conservation of mass is approximated by the incompressible continuity equation

$$
\partial v_{x} / \partial x+\partial v_{z} / \partial z=0
$$

The 2-D Stokes equations take the form:

$$
\begin{gathered}
\partial \sigma_{x x} / \partial x+\partial \sigma_{x z} / \partial z=0 \\
\partial \sigma_{z z} / \partial z+\partial \sigma_{x z} / \partial x=\partial P / \partial z-g \rho .
\end{gathered}
$$

We employ viscous rheological constitutive relationships between the stress and strain rate, whose coefficient $\eta$ represents the effective viscosity, which depends on the composition, temperature, pressure, and strain rate:

$$
\begin{gathered}
\sigma_{x x}=2 \eta \varepsilon_{x x}, \sigma_{x z}=2 \eta \varepsilon_{x z}, \sigma_{z z}=2 \eta \varepsilon_{z z}, \\
\varepsilon_{x x}=\partial v_{x} / \partial x, \varepsilon_{x z}= \\
1 / 2\left(\partial v_{x} / \partial z+\partial v_{z} / \partial x\right), \varepsilon_{z z}=\partial v_{z} / \partial z .
\end{gathered}
$$

We adopt (Gerya and Yuen, 2003b) a Lagrangian frame of reference in which the temperature equation with a temperature-dependent thermal conductivity $k(T)$ (Table 1) takes the form

$$
\begin{gathered}
\mathrm{p} C p(D T / D t)=\partial q_{x} / \partial x+\partial q_{\mathrm{z}} / \partial z+H_{r}+H_{s} \\
q_{x}=k(T) \times(\partial T / \partial x), q_{\mathrm{z}}=k(T) \times(\partial \mathrm{T} / \partial \mathrm{z}), \\
H_{r}=\text { constant }, H_{s}=\sigma_{x x} \varepsilon_{\mathrm{xx}}+\sigma_{\mathrm{zz}} \varepsilon_{\mathrm{zz}}+2 \sigma_{\mathrm{xz}} \varepsilon_{\mathrm{xz}},
\end{gathered}
$$

where $D / D t$ represents the substantive time derivative.

The notations in equations 7-10 represent as follows: $x$ and $z$ are, respectively, the horizontal and vertical coordinates in $\mathrm{m}, v_{x}$ and $v_{z}$ are components of the velocity vector $\underline{v}$ in $\mathrm{m}^{\cdot{ }^{\mathrm{s}-1}} ; t$ is time in $\mathrm{s} ; \sigma_{x x}$, $\sigma_{\mathrm{xz}}$, and $\sigma_{\mathrm{zz}}$ are components of the viscous deviatoric stress tensor in $\mathrm{Pa} ; \varepsilon_{\mathrm{xx}}, \varepsilon_{\mathrm{xz}}$, and $\varepsilon_{\mathrm{zz}}$ are components of the strain rate tensor in $\mathrm{s}^{-1} ; P$ is the pressure in $\mathrm{Pa} ; T$ is the temperature in $\mathrm{K} ; q_{x}$ and $q_{z}$ are the horizontal and vertical heat fluxes, respectively, in $\mathrm{W} \cdot \mathrm{m}^{-2} ; \eta$ is the effective viscosity in $\mathrm{Pa} \cdot \mathrm{s}$; $\rho$ is the density in $\mathrm{kg} \cdot \mathrm{m}^{-3} ; g=9.81 \mathrm{~m} \cdot \mathrm{s}^{-2}$ is the gravitational acceleration; $k$ is the thermal conductivity in $\mathrm{W} \cdot \mathrm{m}^{-1} \cdot \mathrm{K}^{-1}$; the isobaric heat capacity $C p$ is set equal to $1000 \mathrm{~J} \cdot \mathrm{kg}^{-1} \cdot \mathrm{K}_{-1}$ (Table 1); and $H_{r}$, and $H_{s}$ denote, respectively, radioactive and shear heat production in $\mathrm{W} \cdot \mathrm{m}^{-3}$.

We employ a recently developed 2-D code (I2VIS) based on finite differences with a moving marker technique allowing for the accurate conservative solution of the governing equations on a rectangular, fully staggered Eulerian grid for multiphase viscoplastic flow. A detailed description of the numerical method as well as algorithmic tests are provided by Gerya and Yuen (2003b).

\section{Numerical Modeling: Choosing the Specific Parameters for This Study}

For reasons of basic reproducible simplicity, and in keeping with the focus on intra-oceanic subduction zones outlined above, we chose a basic subduction zone model initiating in oceanic lithosphere, thus leading to a convergence of oceanic plate vs. oceanic plate. In this way, the model could be built on a well-defined thermal structure of the oceanic lithosphere as a function of its age. Slab dip was considered to be uncritical at the relatively shallow depths of $15-20 \mathrm{~km}$ at which blueschists can be expected to become stable, and should be dictated by the possible bending radius of the oceanic lithosphere. Assuming this to be about $200 \mathrm{~km}$, we set the slab dip at a constant $45^{\circ}$. With these assumptions, we selected as variables the age of the oceanic lithosphere to constrain the thermal structure, and the rate of subduction. In total, 25 combinations of initial slab age (20 to $100 \mathrm{Ma}$ ) and subduction rate ( 2 to $14 \mathrm{~cm} / \mathrm{yr}$ ) were modeled to obtain a systematic data set. The model uses a $400 \times 200 \mathrm{~km} \mathrm{2-D} \mathrm{box}$ with 500,000 markers, implying a resolution of 400 $\mathrm{m}$ for the lithological field. 
To define the P-T conditions of the blueschist facies we accepted the suggestion of Peacock (1992), which incorporates the calculations of Evans (1990) for the definition of the epidote-blueschist facies (Fig. 4). Blue amphiboles in this context are the $(\mathrm{Mg}, \mathrm{Al})$-rich sodic amphiboles glaucophane and ferroglaucophane (Leake et al., 1997), as well as "crossite" as originally defined by Miyashiro (1957). The term "blueschist" is used in its broadest sense, incorporating all isofacial rocks metamorphosed in the P-T field outlined in Figure 4.

\section{Results of the Calculations}

The results of the model calculations are summarized in Figures 5-8. Figures 5 and 6 show selected typical examples of the self-organizational evolution of the 2-D distribution of sediment, crust, mantle, hydrated mantle, etc. of the subduction zone model as defined in Figure 3. The panels in Figure 5 indicate the changes with time of this cross-section as a function of the rate of subduction at a constant age of the lithosphere of $60 \mathrm{Ma}$. The cross-sections are grouped according to the same amount of subduction, and therefore represent different times elapsed after the initiation of subduction (see label for each cross-section). In Figure 6, the subduction rate is kept constant at $8 \mathrm{~cm} / \mathrm{yr}$, and the cross-sections are compared for three ages of lithosphere. Thus these cross-sections are grouped together for comparable stages in development both in time and amount of subduction.

As expected, the fastest subduction rate leads to the earliest appearance of blueschist-facies conditions (Fig. 5). Note however, that these conditions are first reached at different locations in the subducting oceanic crust. For slow subduction of $2 \mathrm{~cm} / \mathrm{yr}$, blueschist-facies conditions first appear in the lower part of the crustal section, i.e., where the isotherms are relatively flat, whereas at subduction rates of $8 \mathrm{~cm} / \mathrm{yr}$ and more these conditions are first reached in the upper and frontal parts of the slab where the isotherms are steep. In Figure 6, it is again apparent that blueschist-facies conditions are first reached at different parts of the "nose" of the subducting basaltic crust. For young crust, the blueschist facies is first developed in the lower parts marked by flat isotherms, whereas in older crust blueschists form in the upper and frontal sections.

All data obtained for the modeled 25 combinations of initial slab age and subduction rate are summarized in Figure 7, where the data are contoured

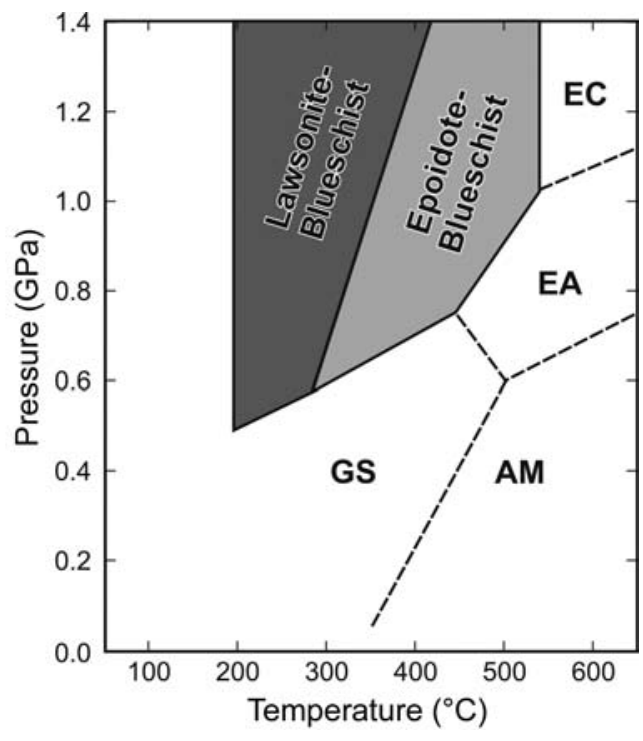

FIG. 4. Pressure-temperature template for blueschist-facies conditions adopted in numerical modeling (Evans, 1990; Peacock, 1992). Abbreviations: GS = greenschist facies; $\mathrm{AM}=$ amphibolite facies; $\mathrm{EA}=$ edpidote-amphibolite facies; $\mathrm{EC}=$ eclogite facies.

both in terms of the time needed after subduction initiation and the convergence necessary to attain blueschist conditions. These diagrams underline the observation made above that time and convergence needed are not simple functions of slab age and convergence rate.

\section{Discussion}

\section{Numerical results}

This numerical study leads to some logical, some unexpected, and also some seemingly non-intuitive results (Fig. 7). It is certainly not surprising that the highest subduction rates should lead to the fastest attainment of blueschist-facies conditions in the subducted slab. On the other hand, we do find it surprising that, for a wide range of slab ages and subduction rates, blueschist-facies conditions can be attained in less than 500,000 years, and for an amount of convergence/subduction of less than 50 $\mathrm{km}$. Even for very low subduction rates of $2 \mathrm{~cm} / \mathrm{yr}$, blueschist-facies conditions can be attained within 2-3 m.y. The amount of required convergence is only moderately dependent on subduction rate (Fig. 7 ), and mainly a function of slab age. Figure 7 indicates that for all values of slab age between 20 and 


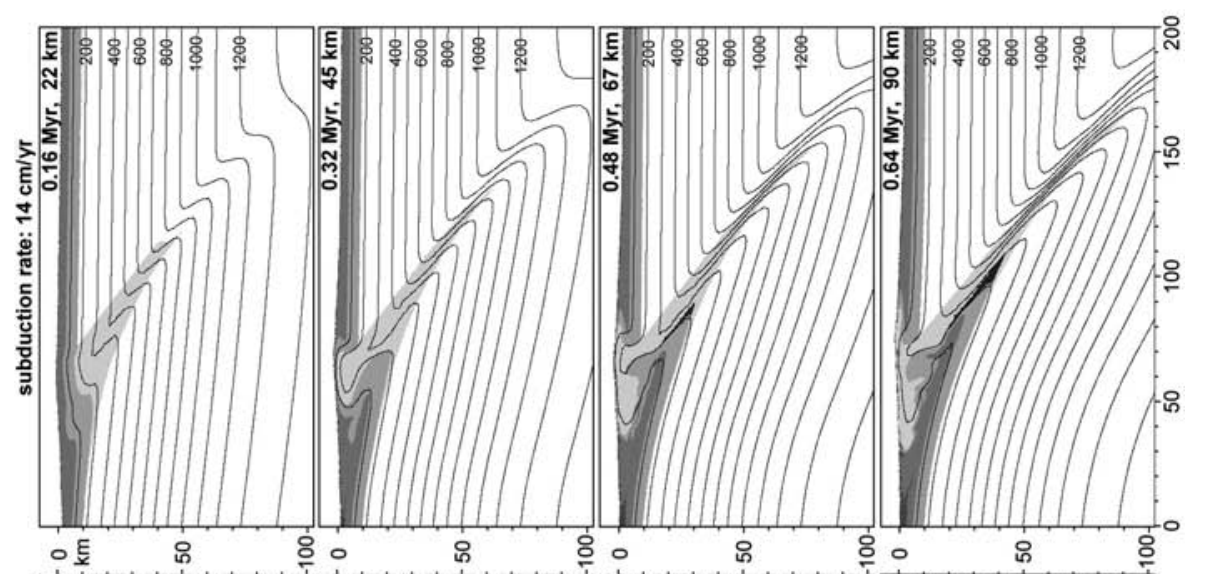

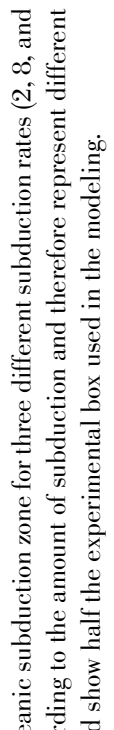

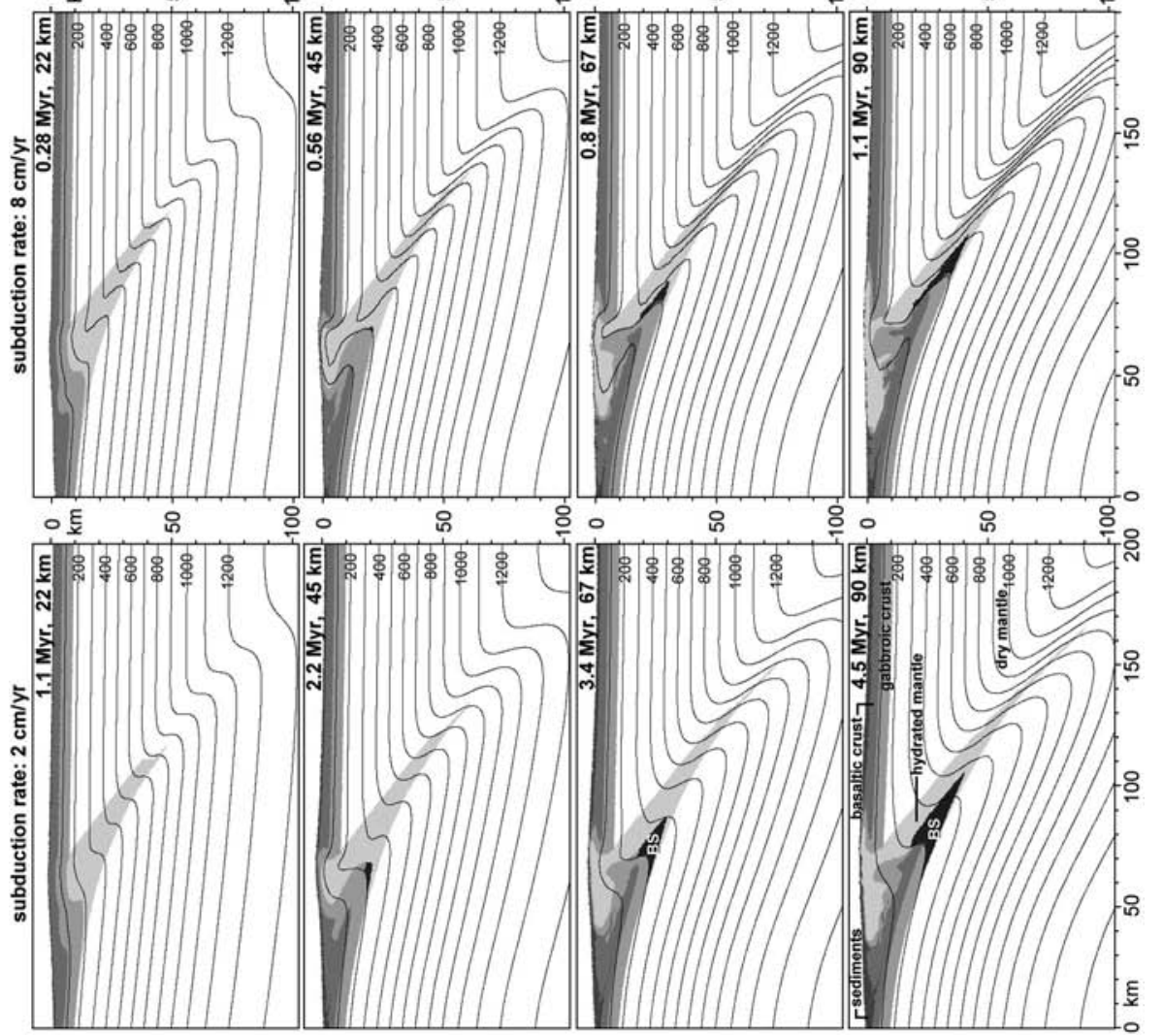

迅 :

สำ

当

त्ञ

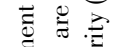

훙 $\frac{\infty}{0}$

훙

要

.

. ํㅠㄹ क

잏

感 $\frac{0}{0}$

월

次

Ð

:

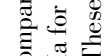

ह

을

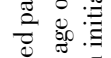

苋:

항

童

总政

10 $\hat{\text { B }}$

है 


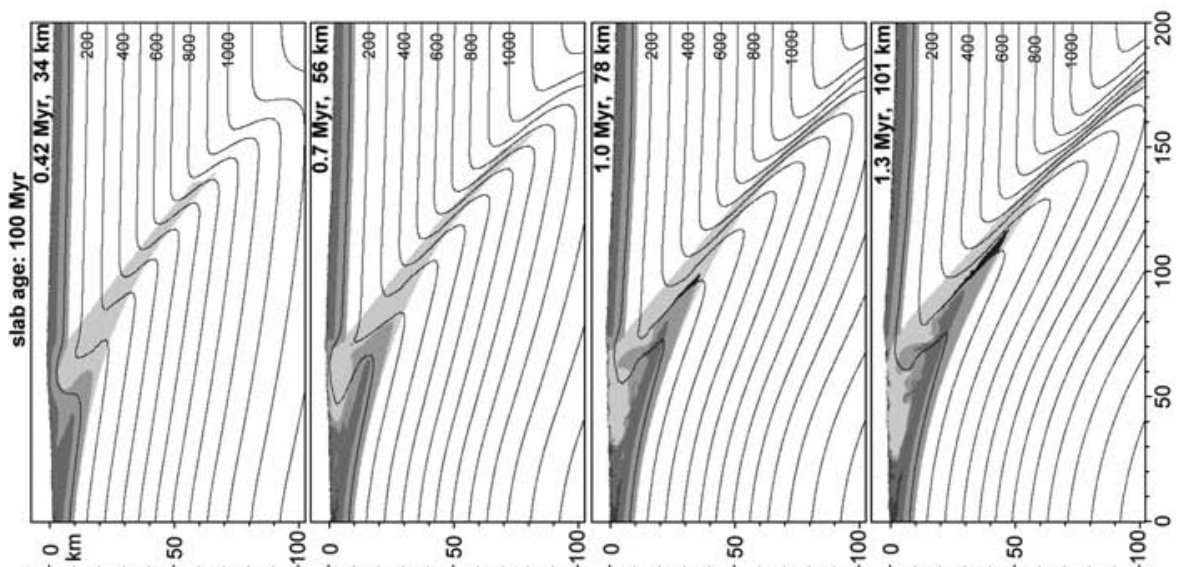

.

离

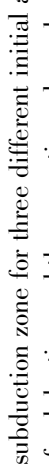
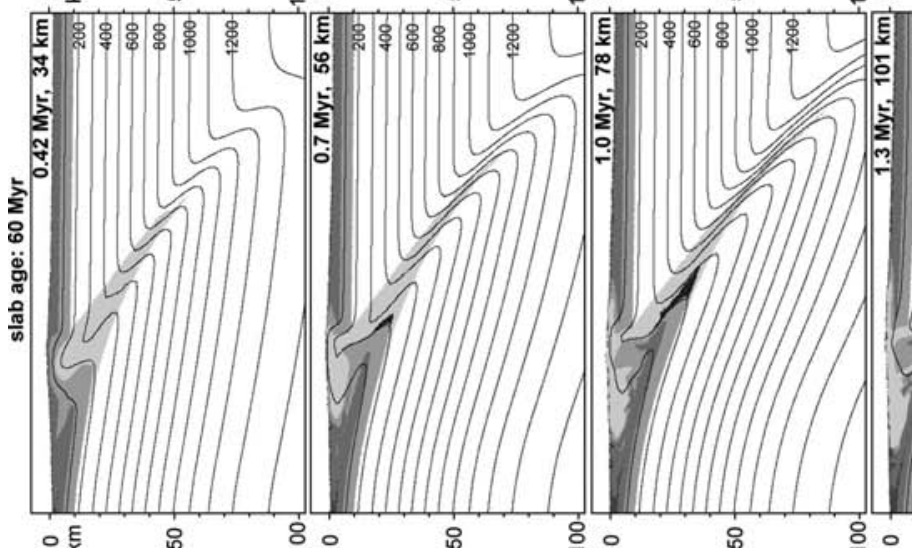

is

10
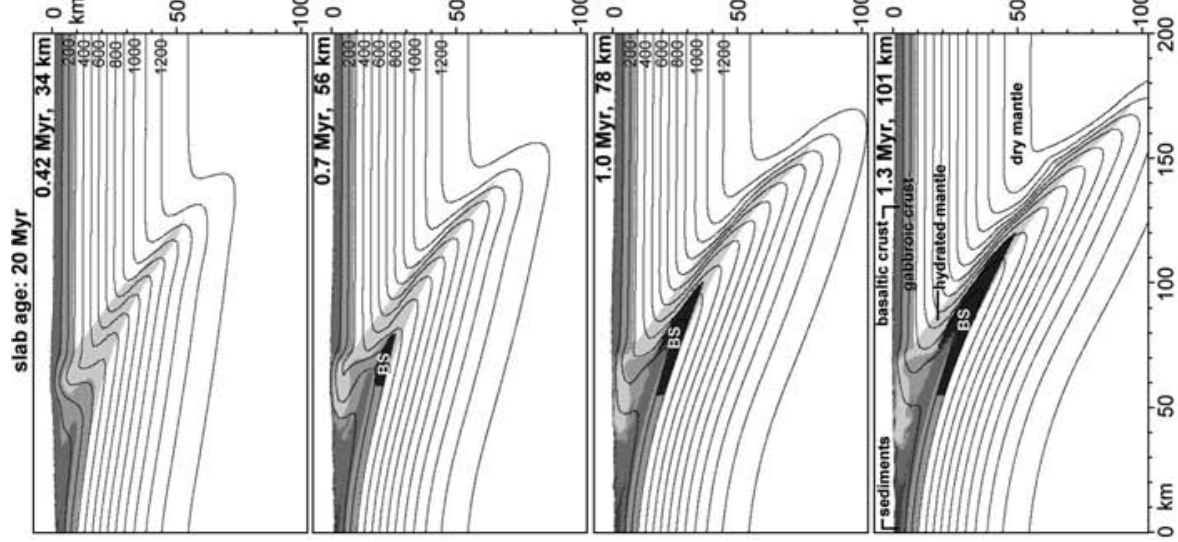

苂 总

용

就

허

항

坖造

웡

造

7 ?

苋

ำ

跑

窇 हैं

焉

๕

શ.

舟

苛

in $\vec{\nabla}$

告焉

D

造

跑 䨔

प) 8

递

छั ठे

$\checkmark$.

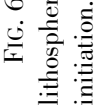



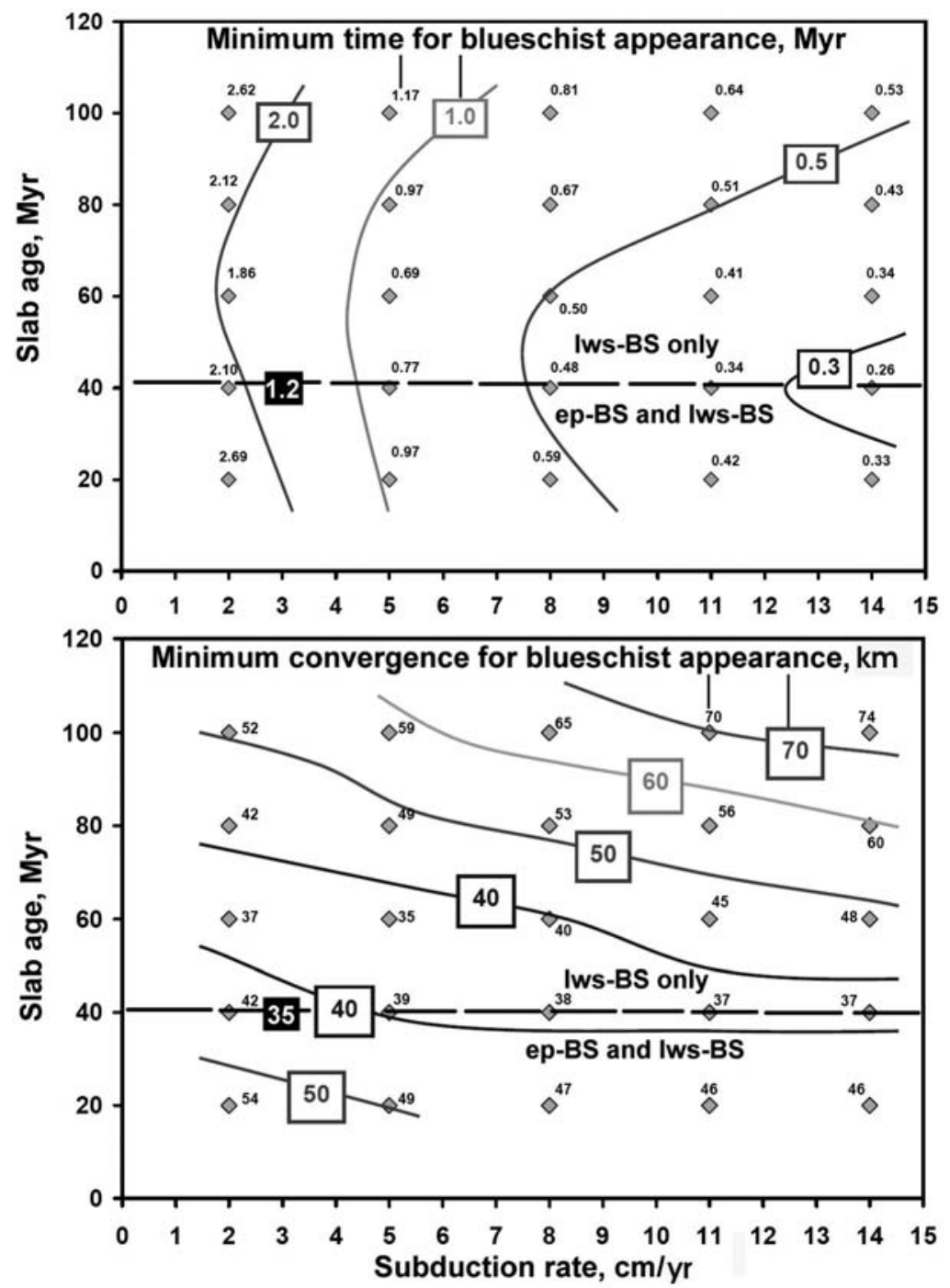

FIG. 7. Summary diagram of slab age vs. subduction rate contoured for equal time elapsed after subduction initiation (upper panel) and minimum convergence needed (lower panel) to reach blueschist-facies conditions. The two data points at $40 \mathrm{Ma}$ and $3 \mathrm{~cm} / \mathrm{yr}$ are taken from an Andean-type subduction model by Stöckhert and Gerya (2005).

$100 \mathrm{Ma}$, as well as all rates of convergence between 2 and $14 \mathrm{~cm} / \mathrm{yr}$, less than $80 \mathrm{~km}$ of convergence are required to reach blueschist-facies conditions. Thus, in the context of Caribbean-, Tethyan-, or western Pacific-type oceanic island-arc scenarios, blueschist formation without any coeval volcanic activity is distinctly possible in many cases of ephemeral subduction.

Surprising, and indeed seemingly non-intuitive, is the result that younger, hotter slabs can lead to earlier blueschist formation than older, cooler slabs. In fact, Figure 7 indicates that there is a distinct optimum for slabs between approximately 40 and 60 Ma of age. This result is a logical consequence of the interplay between the geometry of the subducting slab "nose" and the evolving array of isotherms. The subducting slab can enter the blueschist P-T field from the low-temperature side (i.e., already deep enough but not yet hot enough), or from the low-pressure side (i.e., already hot enough but not 
$20 \mathrm{Myr}$ old slab, $6 \mathrm{~cm} / \mathrm{a}$ : epidote- and lawsonite-blueschists

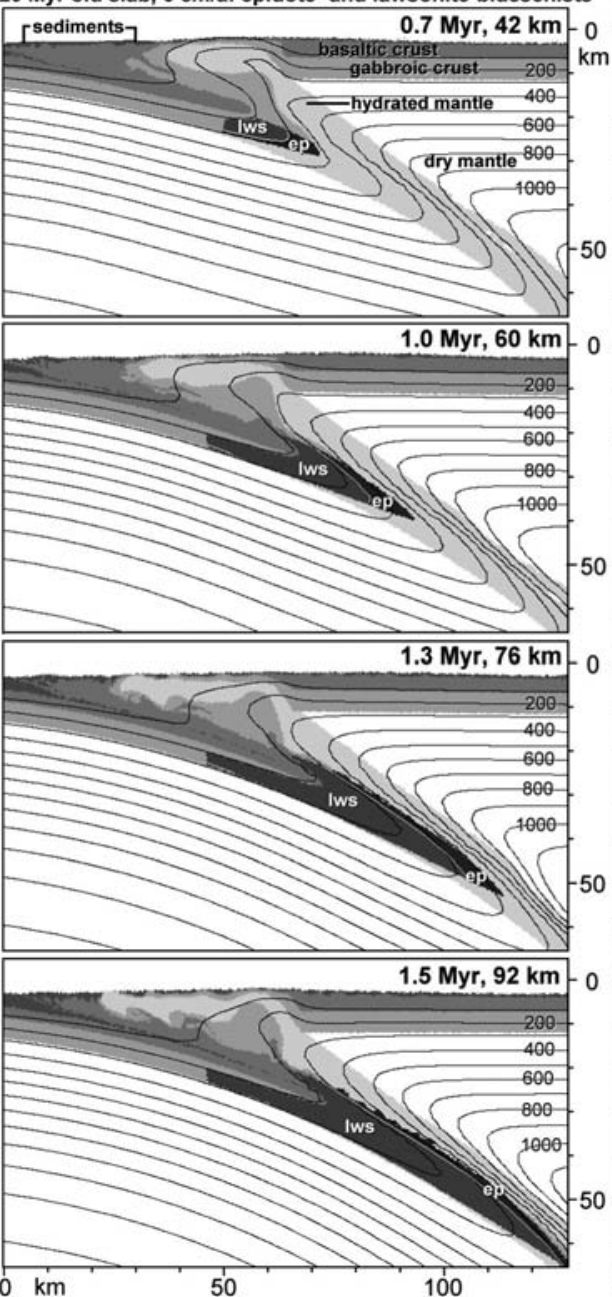

$60 \mathrm{Myr}$ old slab, $6 \mathrm{~cm} / \mathrm{a}$ : lawsonite-blueschists only

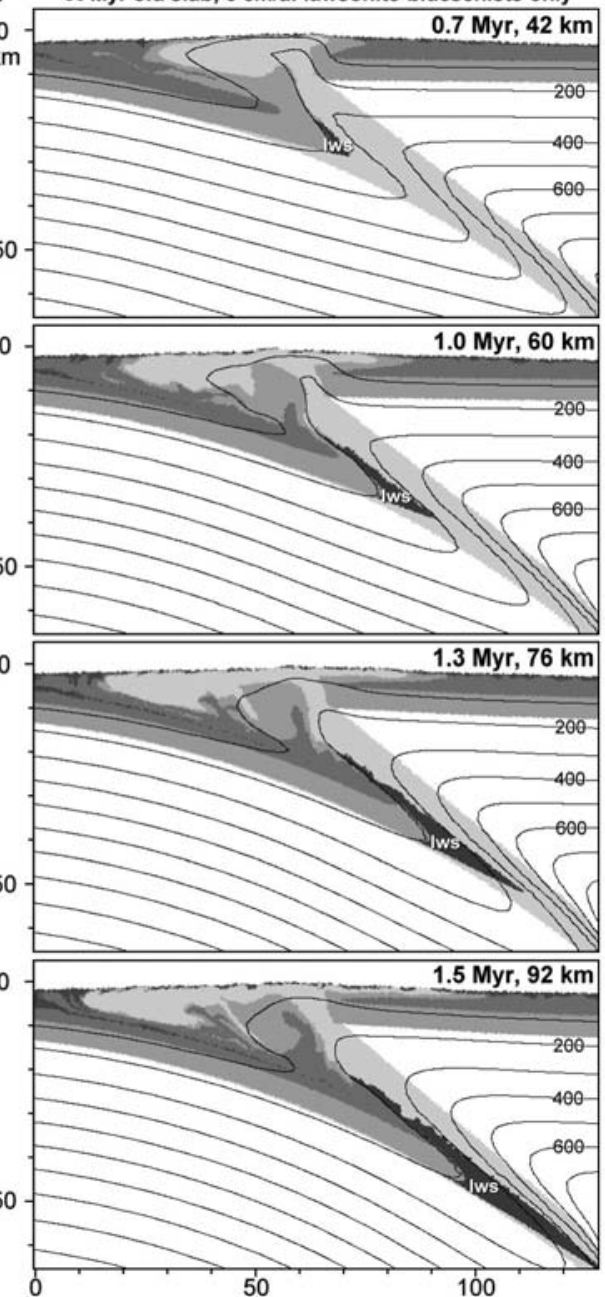

FIG. 8. Sequences of selected panels indicating the development of epidote- vs. lawsonite-blueschist-facies conditions as a function of slab age.

yet deep enough). Between these two geometries there will exist an optimized situation where the slab "nose" will directly "impinge" on the blueschist P-T field at approximately $200^{\circ} \mathrm{C}$ and $0.5 \mathrm{GPa}$ (Fig. 4). Lawsonite-blueschists are the first to form for slabs older than $40 \mathrm{Ma}$ (Figs. 7 and 8). Both epidote- and lawsonite-blueschists form at approximately the same time for the younger slabs (Figs. 7 and 8) that enter the blueschist field from the low-pressure side (Fig. 4), but with time, as the subduction zone matures, lawsonite-blueschist conditions dominate in the subducting slab. In the context of the present intra-oceanic model, it appears that epidote-blue- schists play only a minor role in early blueschist formation.

\section{General significance}

In gauging the significance of the "minima" in time and convergence calculated in this study, it is important to note that we have ignored the influence of reaction kinetics. Even if equilibration in some massive, water-poor rock types may be slow, we assume that amphibole-rich blueschists (i.e., usually strongly deformed, water-rich metavolcanics and metasediments) should probably be a very reactive system. As noted many years ago by Ernst 
(1971), the commonly observed systematic distribution in space and time of high-pressure, low-temperature metamorphic facies in subducted slabs (see also Yardley, 1989; Spear, 1993), and the commonly observed prograde zoning from Fe-rich to (Mg,Al)rich sodic amphiboles (i.e., "crossite" to glaucophane) suggest that large-scale overstepping of the P-T boundaries in Figure 4 should not be a general feature.

Although we have focused here on an intra-oceanic model system characteristic of the Caribbean area (see review by Pindell et al., 2005), where interaction with, and obduction onto, continental margins can shut down the subduction process and allow separation of the prograde path from various possible steady-state exhumation scenarios, the systematic results obtained here can in principle be corroborated by analogous modeling of subduction at a continental margin. Figure 7 includes two data points derived from an Andean-type, continental-margin model calculated by Stöckhert and Gerya (2005). The values do not differ significantly from the results calculated in the present, more systematic study. However, such calculated "minima" become meaningful only when augmented by information on the exhumation path, which is dependent on the specific exhumation scenario involved. Disregarding various possible ad hoc tectonic scenarios (e.g. extension, exhumation during continental collision, etc.) for which no systematic predictions are feasible, it is nevertheless possible to draw on recent quantitative studies of exhumation rates in subduction zones.

Assuming forced return flow in so-called subduction channels (Hsu, 1971; Cloos, 1982; Shreve and Cloos, 1986; Cloos and Shreve, 1988a, 1988b), Gerya and Stöckhert (2002), Gerya et al. (2002), and Stöckhert and Gerya (2005) have numerically investigated the exhumation process for a continental-margin setting with a conceptual model analogous to Figure 3. Maximum exhumation rates are found to vary between about one-sixth of the vertical component of the given subduction rate when assuming uniform power-law rheology for the subduction channel medium (Gerya and Stöckhert, 2002), and up to three times the vertical component of the subduction rate when exhumation is localized in discrete parts of this channel (Stöckhert and Gerya, 2005). Such results are basically in accord with studies based on diffusion rates in mineral grains (e.g., Perchuk et al., 1999) or on geochronology (Rubatto and Hermann, 2001). One caveat to consider, however, is that the subduction zone must mature to a critical stage before return flow from depths greater than about $20 \mathrm{~km}$ is possible (Gerya et al., 2002). Thus only very low-grade blueschists could be recycled in the very early stages of subduction. Gerya et al. (2002) suggested that a mature stage with intense return flow from greater depths should be possible after about 10 m.y. of subduction. With the data now available, a case-to-case appraisal for a given subduction-zone scenario now appears possible.

With regard to the Caribbean setting that prompted this study, we may conclude that extremely short-lived subduction can rapidly produce rocks of the blueschist facies without any correlatable volcanic activity. This may not necessarily simplify paleotectonic interpretation, but it will allow a more realistic appraisal of the significance of the various blueschist occurrences exposed in the circum-Caribbean area (e.g., Pindell et al., 2005). Although the closure of a young, narrow backarc basin as in Figure 2 cannot be considered to be a purely intra-oceanic process, the above discussion indicates that rapid blueschist formation, as in the numerical model studied here, is possible. This can lead logically to intramontane occurrences of blueschist far from the presumed trace of major subduction activity.

\section{Acknowledgments}

We thank W. Gary Ernst for many decades of thought-provoking scientific input. Thanks also to Lorcan Kennan for providing Figure 1 and Frau Renate Lehmann for help with the drafting. Funding by the Deutsche Forschungsgemeinschaft (German Science Foundation) within the scope of the Sonderforschungsbereich SFB 526 (Collaborative Research Center) in Bochum: "Rheology of the Earth-from the upper crust into the subduction zone" is gratefully acknowledged. TVG was also generously supported by the Alexander von Humboldt Foundation, the Russian Foundation for Basic Research (grants \# 03-05-64633 and \#1645-2003-5), and by ETH Research Grant TH-12/04-1.

\section{REFERENCES}

Avé Lallemant, H. G., 1997, Transpression, displacement partitioning, and exhumation in the eastern Caribbean/ South American plate boundary zone: Tectonics, v. 16, p. 272-289. 
Avé Lallamant, H. G., and Guth, L. R., 1990, Role of extensional tectonics in exhumation of eclogites and blueschists in an oblique subduction zone setting: Northeast Venezuela: Geology, v. 18, p. 950-953.

Brace, W. F., and Kohlstedt, D. L., 1980, Limits on lithospheric stress imposed by laboratory experiments: Journal of Geophysical Research, v. 85, p. 6248-6252.

Burke, K., 1988, Tectonic evolution of the Caribbean: Annual Review of Earth and Planetary Sciences, v. 16, p. 210-230.

Clauser, C., and Huenges, E., 1995, Thermal conductivity of rocks and minerals, in Ahrens, T. J., ed., Rock physics and phase relations: Washington, DC, American Geophysical Union, AGU Reference Shelf 3, 1995, p. 105-126.

Clift, P. D., Schouten, H., and Draut, A. E., 2003, A general model of arc-continent collision and subduction polarity reversal from Taiwan and the Irish Caledonides, in Larter, R. D. and Leat, P. T., eds., Intra-oceanic subduction systems: Tectonic and magmatic processes: Geological Society of London Special Publications, v. 219, p. 1-17.

Cloos, M., 1982, Flow melanges: Numerical modelling and geologic constraints on their origin in the Franciscan subduction complex, California: Geological Society of America Bulletin, v. 93, p. 330-345.

Cloos, M., and Shreve, R. L., 1988a, Subduction-channel model of prism accretion, melange formation, sediment subduction, and subduction erosion at convergent plate margins, 1. Background and description: Pure and Applied Geophysics, v. 128, p. 455-500.

Cloos, M., and Shreve, R.L., 1988b, Subduction-channel model of prism accretion, melange formation, sediment subduction, and subduction erosion at convergent plate margins, 2, Implications and discussion: Pure and Applied Geophysics, v. 128, p. 501-545.

Eiler, J., ed., 2004, Inside the subduction factory: American Geophysical Union, Geophysical Monographs Series, v. 138, 324 p.

Ernst, W. G., 1963, Petrogenesis of glaucophane schists: Journal of Petrology, v. 4, p. 1-30.

Ernst, W. G., 1971, Metamorphic zonations on presumably subducted lithospheric plates from Japan, California and the Alps: Contributions to Mineralogy and Petrology, v. 34, p. $43-59$.

Evans, B. W.,1990, Phase relations of epidote-blueschists: Lithos, v. 25, p. 3-23.

Gerya, T. V., and Stöckhert, B., 2002, Exhumation rates of high pressure metamorphic rocks in subduction channels: the effect of rheology: Geophysical Research Letters, v. 29, Article No. 1261

Gerya, T. V., Stoeckhert, B., and Perchuk, A. L., 2002, Exhumation of high-pressure metamorphic rocks in a subduction channel: A numerical simulation: Tectonics, v. 21, p. 6-1 to 6-19.

Gerya, T. V., and Yuen, D. A., 2003a, Rayleigh-Taylor instabilities from hydration and melting propel "cold plumes" at subduction zones: Earth and Planetary Science Letters, v. 212, p. 47-62.

Gerya, T. V., and Yuen, D. A., 2003b, Characteristics-based marker-in-cell method with conservative finite-difference schemes for modeling geological flows with strongly variable transport properties: Physics of the Earth and Planetary Interiors, v. 140, p. 293318.

Gerya, T. V., Yuen, D. A., and Sevre, E. O. D., 2004, Dynamical causes for incipient magma chambers above slabs: Geology, v. 32, p.89-92.

Hacker, B. R., Abers, G. A., and Peacock, S. M., 2003 , Subduction factory 1 . Theoretical mineralogy, density, seismic wave speeds, and $\mathrm{H}_{2} \mathrm{O}$ content: Journal of Geophysical Research, v. 108 [art. no. 2029].

Hsu, K. J., 1971, Franciscan melanges as a model for eugeosynclinal sedimentation and underthrusting tectonics: Journal of Geophysical Research, v. 76, p. $1162-1170$.

Kerr, A. C., Iturralde Vinent, M. A., Saunders, A. D., Babbs, T. L., and Tarney, J., 1999, A new plate tectonic model of the Caribbean: Implications from a geochemical reconnaissance of Cuban Mesozoic volcanic rocks: Geological Society of America Bulletin, v. 111, p. 1581-1599.

Leake, B. E., Woolley, A. R., Arps, C. E. P., Birch, W. D., Gilbert, M. C., Grice, J. D., Hawthorne, F. C., Kato, A., Kisch, H. J., Krivovichev, V. G., Linthout, K., Laird, J., Mandarino, J., Maresch, W. V., Nickel, E. H., Rock, N. M. P., Schumacher, J. C., Smith, D. C., Stephenson, N. C. N., Ungaretti, L., Whittaker, E. J. W., and Youzhi, G., 1997, Nomenclature of amphiboles: Report of the subcommittee on amphiboles of the International Mineralogical Association Commission on New Minerals and Mineral Names: European Journal of Mineralogy, v. 9 , p. $623-651$.

Leat, P. T., and Larter, R. D., 2003, Intra-oceanic subduction systems: Introduction, in Larter, R. D., and Leat, P. T., eds., Intra-oceanic subduction systems: Tectonic and magmatic processes: Geological Society of London, Special Publications, v. 219, p. 1-17.

Maresch, W. V., 1974, The plate tectonic origin of the Caribbean mountain system of northern South America: Discussion and proposal: Geological Society of America Bulletin, v. 85, p. 669-682.

Meschede, M., and Frisch, M., 1998, A plate-tectonic model for the Mesozoic and early Cenozoic history of the Caribbean Plate: Tectonophysics, v. 296, p. 269291.

Miyashiro, A., 1957, The chemistry, optics and genesis of alkali amphiboles: Journal of the Faculty of Science, University of Tokyo, v. 11, p. 57-83.

Peacock, S. M., 1987, Serpentinization and infiltration metasomatism in the Trinity peridotite, Klamath province, northern California: Implications for subduction zones: Contributions to Mineralogy and Petrology, v. 95 , p. $55-70$. 
Peacock, S.M., 1992, Blueschist-facies metamorphism, shear heating, and P-T-t paths in subduction shear zones: Journal of Geophysical Research, v. 97, p. 17,693-17,707.

Perchuk, A. L., Philippot, P., Erdmer, P., and Fialin, M., 1999, Rates of thermal equilibration at the onset of subduction deduced from diffusion modeling of eclogitic garnets, Yukon-Tanana terrain: Geology, v. 27, p. 531-534.

Pindell, J. L., and Erikson, J. P., 1994, The Mesozoic passive margin of northern South America, in Salfity, J. A, ed., Cretaceous tectonics in the Andes: Wiesbaden, Germany, Vieweg Publishing, International Monograph Series, Earth Evolution Sciences, p. 1-60.

Pindell, J. L., and Kennan, L. J. G., 2001, Kinematic evolution of the Gulf of Mexico and the Caribbean, in Fillon, R., ed., Transactions, GCSSEPM Foundation 21st Annual "Bob F. Perkins" Research Conference on "Petroleum Systems of Deep-Water Basins," Houston, Texas December 2-5, 2001, p. 193-220.

Pindell, J. L., Kennan, L., Maresch, W. V., Stanek, K.-P., Draper, G., and Higgs, R., 2005, Plate kinematics and crustal dynamics of circum-Caribbean arc-continent interactions: Tectonic controls on basin development in Proto-Caribbean margins, in Avé Lallemant, H. G., and Sisson, V., eds., Caribbean/South American plate interactions, Venezuela: Geological Society of America Special Paper, in press.

Ranalli, G., 1995, Rheology of the Earth, 2nd ed.: London, UK, Chapman and Hall, 413 p.

Regenauer-Lieb, K., Yuen, D. A., and Branlund, J., 2001, The initiation of subduction: Criticality by addition of water?: Science, v. 294, p. 578-580.

Rubatto, D., and Hermann, J., 2001, Exhumation as fast as subduction: Geology, v. 29, p. 3-6.

Schmidt, M. W., and Poli, S., 1998, Experimentally based water budgets for dehydrating slabs and consequences for arc magma generation: Earth and Planetary Science Letters, v. 163, p. 361-379.

Schott, B., and Schmeling, H., 1998, Delamination and detachment of a lithospheric root: Tectonophysics, v. 296, p. 225-247.

Shreve, R. L., and Cloos, M., 1986, Dynamics of sediment subduction, melange formation, and prism accretion: Journal of Geophysical Research, v. 91, p. 10,22910,245 .

Smith, C. A., Sisson, V. B., Avé Lallemant, H. G., and Copeland, P., 1999, Two contrasting pressure-temperature-time paths in the Villa de Cura blueschist belt, Venezuela: Possible evidence for Late Cretaceous initiation of subduction in the Caribbean: Geological Society of America Bulletin, v. 111, p. 831-848.

Spear, F. S., 1993, Metamorphic phase equilibria and pressure-temperature-time paths: Mineralogical Society of America Special Publication, Washington, DC, $799 \mathrm{p}$.

Stöckhert, B., and Gerya, T. V., 2005, Pre-collisional high pressure metamorphism and nappe tectonics at active continental margins: A numerical simulation: Terra Nova, in press

Tatsumi, Y., and Kogiso, T., 2003, The subduction factory: Its role in the evolution of the Earth's crust and mantle, in Larter, R. D. and Leat, P. T., eds., Intra-oceanic subduction systems: Tectonic and magmatic processes: Geological Society of London, Special Publications, v. 219 , p. 55-80.

Turcotte, D. L., and Schubert, G., 1982, Geodynamics: Applications of continuum physics to geological problems: New York, NY, John Wiley, 430 p.

Yardley, B. W. D., 1989, An introduction to metamorphic petrology: Englewood Cliffs, NJ, Longman Earth Sciences Series, 248 p. 